\title{
Chemical Composition and Antibacterial Activities of the Essential Oils from the Leaves of Premna angolensis and Premna quadrifolia, Two Lamiaceae from Côte d'Ivoire
}

\author{
${ }^{1}$ KOUASSI Kouamé Séraphin, ${ }^{1}$ KOUAME Bosson Antoine*, ${ }^{1}$ MAMYRBÉKOVA-BÉKRO Janat Akhanovna, ${ }^{1}$ BEKRO Yves- \\ Alain, ${ }^{2} \mathrm{FOFIE}$ N'guessan Bra Yvette \\ ${ }^{1}$ Laboratoire de Chimie Bio-Organique et de Substances Naturelles, UFR-SFA, \\ Université Nangui Abrogoua, 02 BP 801Abidjan 01, Côte d'Ivoire. \\ ${ }^{2}$ Laboratoire de Pharmacognosie Botanique et Cryptogamie, UFR- Sciences Pharmaceutiques et Biologiques, \\ Université Félix Houphouet-Boigny.
}

\begin{abstract}
This study was conducted with the objective of contributing to the valorization of aromatic and medicinal plants of Côte d'Ivoire. The essential oil (EO) of the leaves of two species of Premna, P. angolensis and $P$. quadrifolia obtained through steam distillation process, were analized through gas chromatography coupled with mass spectroscopy (GC-MS) and their antimicrobial activities was evaluated by agar diffusion method. The yields of EO extracted from the leaves of $P$. angolensis and $P$. quadrifolia are respectively $0.10 \pm$ $0.02 \%$ and $0.40 \pm 0.02 \%$.
\end{abstract}

99.43\% of the total chemical composition of the EO of $P$. angolensis leaves, are composed mainly of hydrocarbon sesquiterpenes $\mathbf{( 7 1 . 9 0 \% )}$ followed by oxygenates $(14.16 \%)$ and monoterpenes $(13.22 \%)$. The main compounds found are $\beta$-caryophyllene $(33.07 \%)$ and Humulene (10.78\%). The EO of $P$. quadrifofia leaves, $99.59 \%$ of the composition was identified. It contains hydrocarbon sesquiterpenes (89.15\%), followed by oxygenates compounds $(8.61 \%)$ and monoterpenes $(\mathbf{1 . 8 3} \%)$. The major compounds are $\alpha$ bulnesene (23.33\%), germacrene $D(18.83 \%)$ and caryophyllene $(\mathbf{1 8 . 0 6 \%})$. The antimicrobial tests have shown that EO of $P$. quadrifolia leaves has no activites on studied strains and $\boldsymbol{P}$. angolensis oil has a mild activity on Staphylococcus epidermidis and Klebsielle pneumoneae and a weak sensibility on Staphylococcus aureus CIP 4.83 and Candida albicans ATCC 10231. This study highlights chemical composition of the EO from $P$. angolensis and $P$. quadrifolia leaves. It shows more similarities of the chemical compositions of these two species of Premna and the interesting antimicrobial activity potential of $P$. angolensis EO.

Keywords:- Premna angolensis, Premna quadrifolia, essential oil, GC-MS, Côte d'Ivoire.

\section{INTRODUCTION}

Plants are being used for the treatment of several diseases in Côte d'Ivoire, by the populations. Among the species used in traditional Ivorian medicine, many are aromatic plants that produce essential oils. Premna angolensis and Premna quadrifolia are two of these plants used in traditional medicine. The genus Premna comprises about 225 species, distributed mainly in the tropics and sub-tropics. It has already been classified within the family Verbenaceae (Munir, 1984), but has been transferred to the family Lamiaceae (Harley et al. 2004; APG,2009; Olmstead 2010, 2012). Morphologically, most species of the genus Premna are small trees or shrubs and rarely found as lianas (De Kok 2013). Premna angolensis is widely found in tropical Africa, from eastern Senegal to Ethiopia, Kenya, Tanzania and Angola. Small to mediumsized tree up to $21(-33) \mathrm{m}$ tall, less often shrubby; bole up to $120 \mathrm{~cm}$ in diameter, often curved, sometimes fluted, usually hollow (Chase et Reveal, 2009 ; Haston et al., 2009). In Côte d'Ivoire the bark of $P$. angolensis are used in enemas and baths to treat fever in children. In several other countries, $P$. angolensis is used in traditional medicine (Burkill, 2000; Bolza et Keating, 1972 ; Fernandes, 2005 ; Lovett et al.,2006 ; Verdcourt,1992 ).

Premna quadrifolia is a shrub or small tree growing up to 3.5 meters tall. Tree of edges of gallery with downy leaves. Crumpled young shoots exhale a very bad odor (Vergiat, 1970). Several uses are to be noted, in particular to treat malaria, diarrhea, stomach disorders, headaches, coughs, tuberculosis, and infectious diseases such as leuchorrea, genital diseases, cancerous wounds, bad breath and white tongue (Girardi et al. 2015; Perry and Metzger, 1980 ; Quattrocchi , 2012 ; Sharma et coll. 2014). However, the $E O$ of the leaves of these plants are not yet been biologically investigated to our knowledge in Côte d'Ivoire. 
The main objective of this work was to determine the chemical composition and antibacterial activities of EO extracted from the leaves of $P$. angolensis and $P$. quadrifolia, two aromatic plant species collected in Côte d'Ivoire.

\section{MATERIAL AND METHODS}

\section{$>$ Plant material and steam distillation}

The plant material consisted of dry leaves of $P$. angolensis and P. quadrifolia leaves from Prikro (7- 10' 59.999" N 4- 55' 0.001" W). The plants were identified by a botanist technician from the Swiss Center for Scientific Research in Côte d'Ivoire (CSRS, Adiopodoumé - Côte d'Ivoire) and authenticated at the National Floristic Center (CNF) of Abidjan using the existing herbarium, under the number UCJ017472 for P. quadrifolia and UCJ017453 for $P$. angolensis. The materials were dried at room temperature. The EO extraction was carried out in 4 hours through a steam-distillation technique. The steam distillation technique consisted of a four-compartment stainless steel device, used to extract essential oils from the plant. The boiler (capacity: 601 ) was connected to a large tank by a stainless steel pipe. The large tank (height: 100 $\mathrm{cm}$, internal diameter: $51 \mathrm{~cm}$, i.e. a volume of $0.2 \mathrm{~m}^{3}$ ) contains four grids attached to a removable rod. On the grids, the leaves were placed. From this tank, the water vapor drives the volatile compounds into a third tank (height: $100 \mathrm{~cm}$, internal diameter: $41 \mathrm{~cm}$, ie a volume of $0.13 \mathrm{~m}^{3}$ ) which served as a refrigerant. The EO are obtained in a fourth compartment serving as a recovery system.

\section{$>$ GC-MS analysis:}

A GC (7890A, Agilent Technologies) instrument coupled with MS (5975C, Agilent Technologies). The liquid sample volume of $1 \mu \mathrm{l}$ was injected to a liner with $250^{\circ} \mathrm{C}$ and a split ratio of 100:1. The capillary column HP$5 \mathrm{MS}$ was used. Oven temperature programming was as follows: $40^{\circ} \mathrm{C}$ (hold $5 \mathrm{~min}$ ), then a rate of $2^{\circ} \mathrm{C} / \mathrm{min}$ to $250^{\circ} \mathrm{C}$; then a rate of $10^{\circ} \mathrm{C} / \mathrm{min}$ to $300^{\circ} \mathrm{C}$. The carrier gas helium flow was $1 \mathrm{~mL} / \mathrm{min}$. The source and transfer line of MS detector were at 230 and $280^{\circ} \mathrm{C}$, respectively, while the detector voltage was $1.4 \mathrm{kV}$, and the scan range of mass-tocharge ratio of ion was 40-500.

\section{Evaluation of in vitro antibacterial activities}

The strains used for sensitivity studies of the Essential Oils were Staphylococcus auréus CIP 4.8 ; Staphylococcus épidermidis CIP.53124; Salmonella typhimirium SO 66; Eschérichia coli ATCC 25922; Klébsiella pneumoneae; Pseudomonas aéruginosa ATCC 27853 ; Bacillus subtulis ATCC 6633 ;Candida albicans ATCC 10231; Candida tropicalis ATCC 13803 et Candida glabrata ATCC 66032 obtained from the laboratory of Suisse Center for scientific research in Côte d'Ivoire. The antibacterial activity of the EO against each bacterial strain at different concentrations was determined using the method of Berghe and Vlietinck (Berghe et Vlietinck, 1991). The inoculum of $1 \mathrm{~mL}$ was sown in a culture for 18 hours to 20 hours $\left(10^{5}-10^{6}\right.$ $\mathrm{UFC} / \mathrm{mL}$ ), on Mueller-Hinton agar . After $15 \mathrm{~min}$, wells were cut using Pasteur pipettes. The bottom of the wells were closed with a drop of $\mathrm{MH}$ agar to limit the diffusion of the oils under the agar. Then, $50 \mu \mathrm{L}$ of the oil at different dilutions was distributed into each well. After diffusion, cultures were incubated in incubators at $37^{\circ} \mathrm{C}$ for 24 hours. Inhibition rings were measured with a caliper. $0.1 \mathrm{~mL}$ of 18 hours broth of Escherichia coli, Salmonella, Bacillus, klebsiella, candida was transplanted into $10 \mathrm{~mL}$ of $\mathrm{MH}$ broth and $0.3 \mathrm{~mL}$ for Staphylococcus aureus and epidermidis. Incubated at $37^{\circ} \mathrm{C}$ for 3 to 5 hours until the appearance of a slight opalescence of about $5,10^{7}$ bacteria/mL. Then $1 \mathrm{~mL}$ of these broths ware added to 10 $\mathrm{mL}$ of $\mathrm{MH}$ broth previously heated to $37^{\circ} \mathrm{C}$ (inoculum). Then $100 \mu \mathrm{L}$ of the essential oil extract solution was placed in column No. 12 of the microplate, $50 \mu \mathrm{L}$ of $\mathrm{MH}$ broth from column No. 11 to column No. 2 and $100 \mu \mathrm{L}$ of $\mathrm{MH}$ broth in column 1. A dilution from column no. 12 to column no. 3 , taking $50 \mu \mathrm{L}$ each time, and $50 \mu \mathrm{l}$ of the inoculum was distributed into each well of columns no. 12 to no. 2 . The reading was made with the naked eyes after incubation at $37^{\circ} \mathrm{C}$ for 18 hours. The concentration of the last cup where there is no turbidity was also noted. The antibiotics Amphotericin B and Gentamicin were used as references.

\section{RESULTS AND DISCUSSION}

\section{$>$ Extraction yield and Chemical composition of the EO}

The EO extracted from the leaves of $P$. angolensis and $P$. quadrifolia are yellow, they have an aromatic odor with yields of $0.10 \pm 0.02 \%$ and $0.40 \pm 0.02 \%$ respectively. These yields, which could be attributed to the distillation technique, was calculated by the quotient of the mass of EO extracted to the mass of the distilled plant material, are good in view of several yields published on plants harvested in Côte d'Ivoire. It's the case for the trunk bark of Cleitopholis patens (0.18-0.23\%), (Ouattara, 2012) and for the leaves of Melanthera scandens (0.012), (Konan, 2015). The genus Premna is not widely known to be high in EO content. Nonetheless, previous studies have reported the EO content to be in a range of 0.056 to $0.102 \%$ in some species of Premna ( Narayan et Muthana, 1953; Teai et al. 1998; Chanotiya et al. 2009; Rahman et al. 2011; Sadashiva et al. 2013; Adjalian et al. 2015). The identification of their constituents was carried out by GCMS. The retention indices were determined from the retention times (Kovats, 1958; IUPAC, 1997). Twentyseven (27) compounds were identified in the EO of the leaves of $P$. angolensis, about $99.43 \%$ of total composition (Table1).The chemical composition of the EO contains $71.90 \%$ of hydrocarbon sesquiterpenes, $14.16 \%$ of oxygenated compounds, $13.22 \%$ of monoterpenes and $0.15 \%$ of alkenes. The main compounds are $\beta$ caryophyllene $(33.07 \%)$ and humulene $(10.78 \%)$. These results are quite similar to those found in the literature. Adjalian and al. (2015) analyzed by GC-MS, the EO of the leaves of $P$. angolensis. They identified twenty-nine (29) compounds of which the most predominant are the hydrocarbon sesquiterpenes $(26.6 \%)$ and oxygenated sesquiterpenes $(20 \%)$. The major compounds were octen-3ol $(28 \%)$ and (E) - $\beta$-caryophyllene (13.5\%). 
ISSN No:-2456-2165

With regard to its total chemical composition, the essential oil from the leaves of $P$. quadrifolia we identified 36 compounds, about $99.38 \%$ (Table 2). Mainly consisted of hydrocarbon sesquiterpenes $(89.15 \%)$, oxygenated compounds $(8.61 \%)$ and monoterpenes $(1.61 \%)$. The main compounds are $\alpha$-bulnesene $(23.33 \%)$, germacrene D $(18.83 \%)$ and caryophyllene (18.06\%). Adjalian et al. (2015) had performed a GC-MS analysis of the EO of the leaves of this plant which gave similar results. They revealed forty-two (42) compounds, the most predominant of which are sesquiterpenes $(65.5 \%)$. The predominant compounds are $\beta$-elemene $(21 \%)$ and $\beta$-caryophyllene (13.1\%) (Adjalian et al. 2015).

According to these results, several compound well distributed in the two species of Premna studied in varying concentrations. But they are different major compounds.

\begin{tabular}{|c|c|c|c|c|c|}
\hline Number & Compounds & RT (min) & RI & $\mathbf{m} / \mathbf{z}$ & $\begin{array}{l}\% \text { of } \\
\text { total }\end{array}$ \\
\hline 1 & $\alpha$-Pinene & 12.8 & 927 & 136 & 0.24 \\
\hline 2 & Sabinene & 15.5 & 969 & 136 & 1.68 \\
\hline 3 & $\beta$-Myrcene & 16.9 & 991 & 136 & 6.14 \\
\hline 4 & D-Limonene & 19.2 & 1025 & 136 & 4.82 \\
\hline 5 & $\gamma$-terpinene & 20.9 & 1048 & 136 & 0.34 \\
\hline 6 & $\alpha$-Cubebene & 41.4 & 1345 & 204 & 0.47 \\
\hline 7 & Copaene & 43.0 & 1370 & 204 & 5.60 \\
\hline 8 & $\beta$-Elemene & 44.1 & 1387 & 204 & 7.64 \\
\hline 9 & 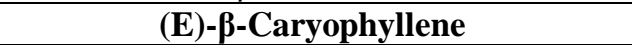 & 45.6 & 1412 & 204 & 33.07 \\
\hline 10 & Humulene & 47.7 & 1446 & 204 & 10.78 \\
\hline 11 & 1,8-Nonadiene, 2-methyl-5,7-dimethylene- & 48.1 & 1453 & 161 & 0.15 \\
\hline 12 & (Z)- $\beta$-Caryophyllene & 48.3 & 1457 & 204 & 0.42 \\
\hline 13 & Germacrene D & 49.4 & 1475 & 204 & 7.54 \\
\hline 14 & (+)-Eremophilene & 50.3 & 1489 & 204 & 0.83 \\
\hline 15 & $\alpha$-Muurolene & 51.5 & 1509 & 204 & 1.13 \\
\hline 16 & Cadina-1(10),4-diene & 52.1 & 1519 & 204 & 3.28 \\
\hline 17 & Germacrene B & 53.8 & 1549 & 204 & 0.36 \\
\hline 18 & beta-Farnesene & 54.6 & 1564 & 204 & 0.78 \\
\hline 19 & Caryophyllene oxide & 55.3 & 1584 & 222 & 6.89 \\
\hline 20 & 6-epi-Cubenol & 56.8 & 1601 & 222 & 1.29 \\
\hline 21 & Epi-Cadinol & 58.7 & 1635 & 222 & 0.58 \\
\hline 22 & Selin-11-en-4-ol & 59.1 & 1643 & 222 & 0.26 \\
\hline 23 & $\alpha$-Eudesmol & 59.4 & 1649 & 222 & 0.35 \\
\hline 24 & $\alpha$-Cadinol & 60.2 & 1663 & 222 & 0.40 \\
\hline 25 & Phytone & 69.7 & 1845 & 250 & 1.22 \\
\hline 26 & Phytol & 82.3 & 2114 & 296 & 2.80 \\
\hline 27 & Phytolacetate & 83.5 & 2200 & 338 & 0.37 \\
\hline \multicolumn{5}{|c|}{ Monoterpenes } & 13.22 \\
\hline \multicolumn{5}{|c|}{ Sesquiterpenes } & 71.90 \\
\hline \multicolumn{5}{|c|}{ Oxygenated Compounds } & 14.16 \\
\hline \multirow{2}{*}{\multicolumn{5}{|c|}{$\begin{array}{c}\text { Others } \\
\text { Total }\end{array}$}} & 0.15 \\
\hline & & & & & 99.43 \\
\hline
\end{tabular}

RT : RetentionTime ; RI : Retention Indice

Table 1:- Constituents identified in the EO of P. angolensis leaves

\begin{tabular}{|c|c|c|c|c|c|}
\hline Number & Compounds & RT (min) & RI & $\mathbf{m} / \mathbf{z}$ & \% of total \\
\hline $\mathbf{1}$ & $\alpha$-Pinene & 12.7 & 927 & 136 & 0.40 \\
\hline $\mathbf{2}$ & Sabinene & 15.5 & 969 & 136 & 0.78 \\
\hline $\mathbf{3}$ & D-Limonene & 19.2 & 1025 & 136 & 0.43 \\
\hline $\mathbf{4}$ & $\alpha$-Cubebene & 41.4 & 1345 & 204 & 0.06 \\
\hline $\mathbf{5}$ & Copaene & 42.7 & 1366, & 204 & 0.23 \\
\hline $\mathbf{6}$ & $\alpha-$-Ylangene & 43,0 & 1370 & 204 & 1.38 \\
\hline $\mathbf{7}$ & $\beta$-Elemene & 43.7 & 1381 & 204 & 0.13 \\
\hline $\mathbf{8}$ & $\beta-$-Cubebene & 44.1 & 1388 & 204 & 5.39 \\
\hline $\mathbf{9}$ & Caryophyllene & $\mathbf{4 5 . 6}$ & $\mathbf{1 4 1 2}$ & $\mathbf{2 0 4}$ & $\mathbf{1 8 . 0 6}$ \\
\hline $\mathbf{1 0}$ & (+)-Calarene & 46.2 & 1422 & 204 & 0.19 \\
\hline $\mathbf{1 1}$ & $\alpha-$-Guaiene & $\mathbf{4 6 . 9}$ & $\mathbf{1 4 3 4}$ & $\mathbf{2 0 4}$ & $\mathbf{1 3 . 4 8}$ \\
\hline
\end{tabular}


ISSN No:-2456-2165

\begin{tabular}{|c|c|c|c|c|c|}
\hline 12 & Humulene & 47.7 & 1446 & 204 & 4.16 \\
\hline 13 & (Z)- $\beta$-Caryophyllene & 48.3 & 1457 & 204 & 0.23 \\
\hline 14 & (E)-Dodec-2-enol & 48.7 & 1462 & 189 & 0.02 \\
\hline 15 & Germacrene D & 49.4 & 1475 & 204 & 18.83 \\
\hline 16 & (+)-Eremophilene & 50.3 & 1488 & 204 & 1.62 \\
\hline 17 & $\alpha$-Bulnesene & 51,0 & 1500 & 204 & 23.33 \\
\hline 18 & Cadina-1(10),4-diene & 52.1 & 1520 & 204 & 0.82 \\
\hline 19 & Germacrene B & 53.8 & 1549 & 204 & 1.22 \\
\hline 20 & palustrol & 54.9 & 1569 & 222 & 0.24 \\
\hline 21 & Caryophyllene oxide & 55.3 & 1575 & 222 & 1.88 \\
\hline 22 & $\beta$-Elemenone trans & 55.9 & 1586 & 222 & 0.12 \\
\hline 23 & $\alpha$-Guaiol & 56.4 & 1594 & 222 & 0.39 \\
\hline 24 & 6-epi-Cubenol & 56.8 & 1602 & 222 & 0.52 \\
\hline 25 & 1,10-di-epi-Cubenol & 57.2 & 1609 & 222 & 0.13 \\
\hline 26 & 4(15)-Eudesmen-6-ol & 57.4 & 1613 & 222 & 0.16 \\
\hline 27 & (+)-epi-Cubenol & 58.05 & 1624 & 222 & 0.35 \\
\hline 28 & Cubenol & 58.5 & 1633 & 222 & 0.86 \\
\hline 29 & Selin-11-en-4-ol & 59.1 & 1643 & 222 & 0.19 \\
\hline 30 & epi $\alpha$-Cadinol & 59.3 & 1648 & 222 & 0.81 \\
\hline 31 & $\alpha$-Cadinol & 60.1 & 1662 & 222 & 0.47 \\
\hline 32 & Germacra-4(15),5,10(14)-trien-1 $\alpha$-ol & 61.1 & 1680 & 222 & 0.14 \\
\hline 33 & (E,E)-Farnesol & 63.0 & 1715 & 222 & 0.1 \\
\hline 34 & Oplopanone & 63.9 & 1732 & 238 & 0.09 \\
\hline 35 & Phytol & 82.3 & 2115 & 297 & 2.03 \\
\hline 36 & Phytolacetate & 83.5 & 2141 & 123 & 0.13 \\
\hline \multicolumn{5}{|c|}{ Monoterpenes } & $1.61 \%$ \\
\hline \multicolumn{5}{|c|}{ Sesquiterpenes } & $89.15 \%$ \\
\hline \multirow{2}{*}{\multicolumn{5}{|c|}{ Oxygenated compounds }} & $8.61 \%$ \\
\hline & & & & & $99.38 \%$ \\
\hline
\end{tabular}

RT : Retention Time ; RI : Retention Indice

Table 2:- Constituents identified in the EO of $P$. quadrifolia leaves.

\section{Antibacterial potential}

After the incubation, there was a zone of inhibited growth around the well, the size of which was related to the antimicrobial capacity of the substance. Results (table 3), showed that the EO of the leaves of $P$. quadrifolia has no activity on bacterial strains and fungi. As for the EO of the leaves of P. angolensis, it has a weak activity on Staphylococcus aureus CIP 4.83 and Candida albicans ATCC 10231. It has a mild activity on Staphylococcus epidermidis and Klebsielle pneumoneae. Indeed the activity is considered nonexistent for a diameter of inhibition (d.i.) less than or equal to $8 \mathrm{~mm}$; weak for d.i. between 8 and $14 \mathrm{~mm}$, mild for d.i. between 14 and $20 \mathrm{~mm}$; strong for d.i. greater than or equal to $20 \mathrm{~mm}$ (Berghe et Vlietinck, 1991). The difference in sensitivity of EO with respect to the strains despite an almost similar composition could be due to the major compounds which are different.

\begin{tabular}{|c|c|c|c|}
\hline & $\begin{array}{c}\text { d.i of EO PA } \\
(\mathrm{mm})\end{array}$ & $\begin{array}{c}\text { d.i of PQ } \\
\text { EO(mm) }\end{array}$ & d.i Gent.(reference)(mm) \\
\hline Bacillus subtulis ATCC 6633 & 00 & 00 & 34 \\
\hline Staphylococcus aureus CIP 4.83 & 10 & 00 & 30 \\
\hline Staphylococcus epidermidis CIP.53124 & 15 & 08 & 30 \\
\hline Pseudomonas aeruginosa ATCC 27853 & 00 & 00 & 30 \\
\hline Salmonella typhimirium SO 66 & 00 & 00 & 28 \\
\hline Escherichia coli ATCC 25922 & 00 & 08 & 35 \\
\hline Klebsielle blse & 15 & 00 & Amphotericin B (reference) \\
\hline Candida albicans ATCC 10231 & & 00 & 35 \\
\hline Candida tropicalis ATCC 13803 & 09 & 00 & 30 \\
\hline
\end{tabular}

d.i : diameter of inhibition

Table 3:- Diameter of inhibition of EO on bacteria and fungi 
The MIC and BMC of the EO of the leaves of $P$. angolensis are determined from the inhibition diameter greater than or equal to $11 \mathrm{~mm}$ (Table 4$)$.

\begin{tabular}{|c|c|c|c|c|}
\hline & MIC mg/ml & MBC mg/ml & MBC/MIC & Effect of the EO \\
\hline Klebsiella pneumoneae & 3.75 & 30 & 8 & bacteriostatic \\
\hline Stahylococcus epidermidis & 3.75 & 30 & 8 & bacteriostatic \\
\hline
\end{tabular}

MIC: Minimal Inhibitory Concentration; MBC : Minimum Bactericidal Concentration

Table 4:- Minimum inhibitory and bactericidal concentration of EO of the leaves of $P$. angolensis

The EO of the leaves of $P$. angolensis is bacteriostatic. It therefore inhibits the multiplication of bacteria without killing them. By inhibiting bacteria, it could work with the immune system to remove the bacteria from the body.

\section{CONCLUSION}

This study allowed us to identify the composition by GC-SM and to evaluate the bacterial activities of EO from the leaves of two Premna from Côte d'Ivoire. EO of the leaves of $P$. angolensis contains $71.90 \%$ of hydrocarbon sesquiterpenes, $14.16 \%$ of oxygenated compounds, $13.22 \%$ of monoterpenes and $0.15 \%$ of alkenes. The main compounds are $\beta$-caryophyllene $(33.07 \%)$ and humulene (10.78\%). And EO from the leaves of $P$. quadrifolia contains hydrocarbon sesquiterpenes $(89.15 \%)$, oxygenated compounds $(8.61 \%)$ and monoterpenes $(1.61 \%)$. The major compounds are $\alpha$-bulnesene $(23.33 \%)$, germacrene D $(18.83 \%)$ and caryophyllene $(18.06 \%)$. The composition of the two species are almost identical.

Antimicrobial tests showed that EO of the leaves of $P$. angolensis oil has a mild activity on Staphylococcus epidermidis and Klebsielle pneumoneae and a weak sensibility on Staphylococcus aureus CIP 4.83 and Candida albicans ATCC 10231. So these activities would justify the use of extract of $P$. angolensis for treatment by the populations. That of P.quadrifolia has no activity on bacterial strains and fungi.

\section{ACKNOWLEDGEMENT}

The authors thank Gwaenael Chamoulaud, Galyna Shul of the University of Quebec at Montréal for the chromatographic analyzes, Téré Henry botanist technician for plant identification and Touré Sadikou, Technician at the Analysis Center of the Swiss Center for scientific research in Côte d'Ivoire for antimicrobial analyzes.

Statement of Conflict of Interest and Source of Funding

The Authors declare absence of any conflicts of interest. In addition, no funding was received.

\section{REFERENCES}

[1]. Adjalian E., Sessou P., Odjo T., Figueredo G., Kossou D., Avlessi F., Menut C., and Sohounhloué D., (2015). Chemical Composition and Insecticidal and Repellent Effect of Essential Oils of Two Premna Species against Sitotroga cerealella. Journal of Insects.6

[2]. Angiosperm Phylogeny Group,(2009). «An update of the Angiosperm Phylogeny Group classification for the orders and families of flowering plants: APG III », Botanical Journal of the Linnean Society, 161(2), p105-121

[3]. Berghe V.D.A., Vlietinck A.J.1991. Screening methods for antibacterial and antiviral agents from higher plants. Methods in plant biochemistry. Hostettman, K Ed., London: Academic press, 1991.

[4]. Bolza, E. \& Keating, W.G., (1972). African timbers: the properties, uses and characteristics of 700 species. Division of Building Research, CSIRO, Melbourne, Australia. 710 pp.

[5]. Chanotiya CS, Yadav AK, Singh AK. (2009). Leaf oil composition of Premna barbata Wall. ex Sch. from Kumaon region of Uttarakhand. J Essent Oil Res. 21:76-77.

[6]. Chase M. W.et Reveal J. L.,(2009). A phylogenetic classification of the land plants to accompany APG III . Bot. J. Linn. Soc. :161, p122127

[7]. De Kok R. (2013). The genus Premna L. (Lamiaceae) in the Flora Malesiana area. Kew Bull. 68:1-30.

[8]. Fernandes, R., (2005). Lamiaceae. In: Pope, G.V. \& Martins, E.S. (Editors). Flora Zambesiaca. Volume 8, part 7. Royal Botanic Gardens, Kew, Richmond, United Kingdom. pp. 61-153.

[9]. Girardi C, Butaud JF, Ollier C, Ingert N, Weniger B, Raharivelomanana P, Moretti C.(2015). Herbal medicine in the Marquesas Islands. J Ethnopharmacol. 161:200-213.

[10]. Harley RM, Atkins S, Budantsev AL, Cantino PD, Conn BJ, Grayer R, Harley MM, de Kok R, Krestovskaja T, Morales $\mathbf{R}$, et al. 2004. The Families and Genera of Vascular Plants. Flowering plants, Dicotyledons: Lamiales (except Acanthaceae including Avicenniaceae) Labiatae. In: Kubitzki K, Kadereit JW, editors. Vol. 7. Berlin: Springer. p. 167-275. 
[11]. Haston E. Richardson J. E. et Stevens P. F. ,(2009) .The linear angiosperm phylogeny group (LAPG) III: a linear sequence of the families in APG III. Bot. J. Linn. Soc. :161, p128-131

[12]. IUPAC.(1997). Compedium of Chemical Terminology, 2è édition (le Livre d'or). Wilkinson Blackwell Scientific Publications, Oxford. P108.

[13]. Konan N. S.(2015).Composition chimique et étude comparative des activités anti-oxydante et antibactérienne des huiles essentielles extraites de 3 plantes de la famille des Asteraceae de Côte d'Ivoire. Thèse Pour obtenir le grade de Docteur de l'Université Nangui Abrogoua. p130.

[14]. Kovats E.(1958). Gas-chromatographische charakteriserung organischer verbidungen. Teil 1: Retentions indices aliphatischer halogenide, Alkohole, Aldehyde und Ketone. Helvetica Chimica Acta: 41(7).

[15]. Lovett, J.C., Ruffo, C.K., Gereau, R.E. \& Taplin, J.R.D.,( 2006). Field guide to the moist forest trees of Tanzania. [Internet] Centre for Ecology Law and Policy, Environment Department, University of York, York, United Kingdom. http://celp.org.uk/ projects/ tzforeco/

[16]. Munir AA.(1984). A taxonomic revision of the genus Premna L. (Verbenaceae) in Australia. Adelaide Bot Gard. 7:1-44.

[17]. Narayan VL, Muthana MS. (1953). Essential oil from Premna tomentosa. J Indian Inst Sci. 35:55-67.

[18]. Olmstead R. (2010). A sypnotical classification of the Lamiales. Version 2.2. [updated 2016 July 26; cited 2015 Oct 20]. Available from: https://myplant.org/sites/default/files/lamiales_classn. v.2.2_0.pdf.

[19]. Olmstead R. (2012). A sypnotical classification of the Lamiales. Version 2.6.2. [updated 2016 April 12; cited 2015 Oct 20]. Available from: https://depts. washington.edu/phylo/Classification.pdf.

[20]. Ouattara Z. A. (2012). Contribution de la $\mathrm{RMN}^{3} \mathrm{C}$ à la Caractérisation des Huiles Essentielles de Cinq Annonacées Acclimatées en Côte d'Ivoire, Université de corse-pascal paoli école doctorale environnement et société -Université de cocody-abidjan ufr-ssmt. Thèse en Convention de Cotutelle Internationale présentée pour l'obtention du grade de Docteur en Chimie. p225.

[21]. Perry LM, Metzger J. (1980). Medicinal plants of East and Southeast Asia. Attributed properties and uses. Cambridge Massachusetts: The MIT Press.

[22]. Quattrocchi U.(2012). CRC World Dictionary of Medicinal and Poisonous Plants, vol. III (E-L). Boca Rotan Florida: Taylor \& Francis Group.

[23]. Rahman A, Shanta ZS, Rashid MA, Parvin T, Afrin S, Khatun MK, Sattar MA. (2011). In vitro antibacterial properties of essential oil and organic extracts of Premna integrifolia Linn. Arabian J Chem. 9:S475-S479.

[24]. Sadashiva CT, Sharanappa P, Naidoo Y, Balachandran I. (2013). Chemical composition of essential oil from the leaves of Premna coriacea Clarke. Afr J Biotechnol. 12:2914-2916.
[25]. Sharma J, Gairola S, Sharma YP, Gaur RD. (2014). Ethnomedicinal plants used to treat skin diseases by Tharu community of district Udham Singh Nagar, Uttarakhand, India. J Ethnopharmacol. 158:140-206.

[26]. Verdcourt, B., (1992). Verbenaceae. In: Polhill, R.M. (Editor). Flora of Tropical East Africa. A.A. Balkema, Rotterdam, Netherlands. 155 pp. 